(C) Єхалов В. В., Седінкін В. А., Бараннік С. І., 2017

Схалов Василь Віталійович, Седінкін Владислав Анатолійович,

Бараннік Сергій Іванович

Державний заклад

«Дніпропетровська медична академія МОЗ України»

\title{
«КЛІПОВЕ МИСЛЕННЯ» \\ ТА СУЧАСНА ВИЩА МЕДИЧНА ОСВІТА
}

Проаналізовано позитивні та негативні сторони «кліпового мислення» та його вплив на процес навчання у вищої медичної освіті. Розглядається та запропоновано методи мімінізаиіі негативного впливу «кліпового мислення» в прочесі підготовки фахівців. Застосування відомих методів навчання спільно з новими розробками, в тому числі i e-learning технологіями підвищить ефективність прочесу навчання $і$ значно поліпшить рівень професійної підготовки.

Ключові слова: «кліпове мислення», вища медична освіта, освітній проиес.

Проблема, іï зв'язок із важливими науковими чи практичними завданнями. Посилення ролі інформації, інформаційних технологій призвело до того, що сучасне суспільство існує на новому етапі розвитку - інформаційному. Виникає принципово новий спосіб комунікації та трансляції інформації, який отримав назву «екранної культури». Вплив інформаційного суспільства торкається сфери суспільства людей, їх навчання та процесів управління. Під його впливом відбувається зміна мислення, в зв'язку з чим все частіше в науковій літературі з'являються такі поняття, як «людина-екран», «кліпове мислення», «кліпова свідомість» [1].

У зв'язку з інформатизацією освіти, яку сьогодні вважають майже панацеєю, виникають ризики втрати творчої культурногенеруючої здатності цілих поколінь. Якщо старше покоління ще зберегло й інші форми сприйняття наданої інформації (осмислення, порівняння, аналіз, критику, тощо), то в молодого покоління, i студентів у першу чергу, все більше виявляється динамічне, мозаїчне, «кліпове» отримання, переробка та надання образності інформації, насамперед - навчальної [2]. 
Аналіз публікацій (виділення невирішених проблем). «Кліпове мислення» як явище - це відповідь на зростання кількості інформації. ЗМІ виробили універсальний формат подачі інформації, суть якого полягає в тому, щоб подати набір тез або кліпів без визначення контексту, тому що в силу своєї актуальності контекстом для тези є об'єктивна дійсність. Іншими словами, універсальний формат 3МI змушує вважати події пов'язаними, якщо вони мають тимчасову спорідненість, а не фактологічну. Суспільство, перебуваючи на сучасному етапі розвитку, трансформується в «електронне суспільство» або «глобальне село» і задає, за допомогою електронних засобів комунікації, багатовимірне сприйняття світу. Розвиток електронних засобів комунікації повертає людське мислення до дотекстової епохи, і лінійна послідовність знаків перестає бути базою культури (Г. М. Мак-Люэн, 2003). У психології, педагогіці та журналістиці таке мислення характеризують як фрагментарне i алогічне (Т. В. Семеновських, 2014), несистемне (С. В. Докука), переважно візуальне і асоціативне (С. О. Жукова, Н. Ю. Комірна), архаїчне i позбавлене тимчасових i просторових категорій (Т. М. Шеметова). У індивіда зникає необхідність запам'ятовувати інформацію, конспектувати іiі та осмислювати. Він перестає опановувати об'єкти пізнання, зважаючи на те, що вони ілюзорно доступні. Така специфіка запам'ятовування «електронної особистості» тягне за собою відповідні зміни мислення - скорочується кількість бажаних, шуканих, значущих, невідомих об'єктів. I думка, що розгубила свої проблемні складові, припиняє породжувати думки, образи, символи, ідеї [3].

Мета публікації полягає в аналізі ролі «кліпового мислення» та його впливу на навчальний процес у вищих медичних закладах.

Виклад основного матеріалу, обгрунтування результатів дослідження. Для початку треба визначити позитивні та негативні сторони «кліпового мислення» та його вплив на процес навчання. До позитивних сторін відносять:

- «Кліповий» спосіб роботи 3 інформацією додає динамізму пізнавальній навчальній діяльності, що дозволяє в умовах зростаючого обсягу навчального матеріалу встигати, іноді хоч би формально, виконати необхідні завдання.

- «Кліпова» поведінка дозволяє бачити багатоплановість, багатоваріантність, неоднозначність підходів до аналізу або вирішення конкретних питань і завдань (таке мислення допомагає аудиторії краще усвідомлювати та розуміти найрізноманітніші зв'язки між явищами та подіями).

- Кліпове мислення може використовуватися як захисна реакція організму на інформаційну перевантаження, сприяє більшій адаптації 


\section{Збірник наукових статей}

до мінливої соціальної реальності та її пізнання; якщо враховувати всю ту інформацію, яку бачить і чує за день людина, плюс «всесвітнє звалище» Інтернет, то немає нічого дивного в тому, що іiі мислення змінюється, підлаштовується, адаптується до нових умов [4].

Більш вагомими є негативні сторони «кліпового» мислення:

- Навколишній світ перетворюється на мозаїку розрізнених, мало пов'язаних між собою фактів, частин, уламків інформації. Людина звикає до того, що вони постійно, як у калейдоскопі, змінюють один другого, постійно вимагає нових надходжень (потреба слухати нову музику, спілкуватися в чаті, постійно «блукати» мережею, редагувати фотографії, дивитися уривки 3 фільмів, грати онлайн з новими учасниками). Це суттєво відволікає їх від головного, «стрижневого» заняття - навчання.

- У студентів негативна «кліповість» виявляється яскравіше: це пов’язано 3 тим, що викладачі вимагають від них вивчати першоджерела, навчальну літературу, конспектувати та аналізувати спеціальну інформацію. А покоління «швидких кнопок» хоче, щоб навчальна інформація надавалася їм у звичній для них стислій, «кліповій» формі (презентації занять, стислі конспекти, опорні схеми, малюнки, тощо). Ці вимоги досить недостатньо враховуються авторами нових освітніх програм, сучасних підручників, тощо.

- Втрачається здібність до аналізу та побудови довгих логічних ланцюжків, споживання інформації прирівнюється до поглинання фаст-фуда (чи можна взагалі отримувати знання, не аналізуючи інформації, яка надається в навчальному процесі?).

- Власникові кліпового мислення важко аналізувати ситуацію, оскільки будь-яка інформація не затримується в його свідомості і швидко змінюється новою. Падає рівень успішності і знижується коефіцієнт засвоєння знань.

- У студентів «кліповість» проявляється більш яскраво і пов'язано це, по-перше, 3 тим, що вони знаходяться «в зоні уваги» викладачів, які вимагають від них читати першоджерела, конспектувати, і коли вони цього не роблять, починається пошук інтерактивних методів навчання та впливу; по-друге, 3 глобальною інформатизацією суспільства за останній десяток років неймовірно прискорився темп обміну інформації, яка вселяє в юнака впевненість у швидкому простому вирішенні складного для нього завдання: навіщо йти в бібліотеку, щоб взяти, а потім прочитати монографію за темою, коли досить відкрити Google, знайти, скачати з мережі найпершу (яка майже ніколи не відповідає сучасним вимогам) інформацію, або відкрито сказати викладачеві (власний досвід): «Навіщо дома готуватися, якщо ви нам все одно все поясните». Це вже формування споживацького підходу до навчання. А може взагалі немає ніякої 
проблеми, а тільки ліннощі та перетворення демократії на анархію? Та ні, кліпове мислення - це вектор у розвитку відносин людини 3 інформацією, яка виникла, не вчора і зникне не завтра [4].

У зв'язку з вищевикладеним ми бачимо необхідність створення альтернативних освітніх програм, зміни структури надання інформації, переклад підручників у цифрову форму з багаторівневою структурою, де перший рівень дозволяв би в термін не більше двадцяти хвилин ознайомитися із загальною ідеєю в парі десятків «абзаців-кліпів», а кожен наступний ішов углиб питання, систематизуючи раніше отримані знання. Книги ж у цій системі координат перейдуть на останній рівень і також будуть змушені якісно змінитися.

Вирішення питання формування клінічного мислення, 3 яким стикаються викладачі старших курсів у медичних вишах, потребує детального вивчення. Неможливість студента, навіть «теоретичного» відмінника, використовувати, систематизувати отримані знання 3 кожним роком викликає все більше невдоволень і веде до зниження професійної підготовки.

Дозволимо собі припустити, що проблемна ситуація сучасного навчального простору полягає в тому, що викладачі - переважно «люди книги», а студенти (інтерни) - переважно «люди екрану», і їм треба навчитися говорити один 3 одним і розуміти один одного. В окремих країнах світу, де стали усвідомлювати небезпеку «кліпового» мислення, розробляються спеціальні тренінги, де навчають зосереджувати увагу на одному предметі й утримувати стан концентрації протягом тривалого часу. Саме на розробку таких тренінгів і має бути спрямовано подальші дослідження із зазначеної теми. При цьому всі фахівці одностайні - найбільш доступним методом мімінізації негативного впливу «кліпового» мислення $\epsilon$ читання «некліпових» літературних джерел [5].

Неабияку роль у формуванні клінічного мислення відіграє зацікавленість студента (інтерна) в процесі навчання. Порівнюючи анонімні анкети лікарів-інтернів та лікарів-курсантів циклів спеціалізації, стажування, тематичного удосконалення та передатестаційних нами було зроблено дуже цікаві спостереження. Коли лікарі-курсанти оцінювали отриманий на циклах навчальний матеріал як «цікавий» $\mathrm{i}$ «корисний», різниця між процентними показниками була мінімальною - 1,6 \pm 0,2\%. Це дозволяє зробити висновок, що для лікаря 3 практичним стажем роботи ці поняття практично ідентичні. Для лікарів-інтернів ця різниця становила $39,2 \pm 0,7 \%$. Це доводить, що термін «цікавий матеріал» в понятті лікаря-інтерна в корені відрізняється від визначення «корисний матеріал». В даному випадку слово «цікавий» більше відповідає терміну «захоплюючий». Визначення «корисний» для них $є$ чимось 


\section{Збірник наукових статей}

неминуче необхідне, що вимагає витрати праці і часу. При аналізі анкет лікарів-інтернів ми 3 кожним роком відзначали прогресивне зниження процентної різниці між цими визначеннями, яка в 2011-2012 навчальному році дорівнювала 7,2 \pm 0,2\%, а у 2016-2017 р. склала вже $6,1 \pm 0,3 \%[6]$.

Доцільно зробити заняття «зовні привабливим» - це може бути ігрова форма, наведення прикладів з власного досвіду, цікаві завдання 3 практичним результатом, тощо. Між викладачем та інтернами повинен постійно відбуватися діалог, їм повинна бути надана можливість самостійно отримати (або закріпити) необхідні практичні навички, засвоїти сучасні діагностичні методи дослідження, а також підготувати теоретичний матеріал у вигляді презентації на вузькоспеціалізовану тему та доповісти всім інтернам 3 подальшим обговоренням. У ході етико-професійної підготовки, орієнтованої на особистість, повинні мати місце суб'єкт-суб'єктні відносини. Зусилля та активні дії всіх учасників освітнього процесу спрямовуються на саморозвиток, самореалізацію власної позитивної «Я» - концепції. Освітній процес покликаний забезпечити цілісність формування професійного та громадянського статусу молодих асистентів при збереженні індивідуальності особистості кожного інтерна. Саме ця вимога $є$ одним 3 важливих аспектів становлення соціально-зрілої особистості професіонала в системі післядипломної освіти [7]. Дуже важливу роль відіграє створення емоційного i психологічного комфорту інтерна у процесі подання навчального матеріалу.

Використання методів активізації діяльності лікарів-інтернів найбільш важливий принцип навчання на післядипломному рівні. Рішення діагностичних і лікувальних завдань, проблемних ситуацій, участь в навчальних іграх забезпечує високу професійну підготовку. В процесі навчання інтерни змушені активно знаходити, вивчати i використовувати навчальну та наукову інформацію, що більш корисно, ніж традиційні способи навчання практичної діяльності. Сучасний виховно-освітній процес актуалізує лідерські якості молодих людей, прищеплюючи їм смак до нового i прогресивного, спонукає до вивчення новітніх медичних технологій.

Одним 3 найважливіших резервів підвищення ефективності вищої освіти $є$ оптимізація самостійної роботи лікарів-інтернів, яка варіює за обсягом від 100\% (при навчанні екстерном) до 30\% (при очній формі навчання). Самостійна підготовка - це планована робота лікарів-інтернів, що виконується за завданням і при методичному керівництві викладача, але без його безпосередньої участі. Цей вид роботи призначений не тільки для оволодіння дисципліною, але для придбання здатності приймати на себе відповідальність, самостійно вирішувати проблему, знаходити конструктивні рішення, вихід із 
кризової ситуації, тощо. Викладач лише організовує самостійну підготовку, а лікар-інтерн сам здійснює пізнання.

\section{Висновки, перспективи.}

1. «Кліпове мислення» відтісняє клінічне мислення, принципи медичної деонтології, сприяє розвитку «фельдшеризму» тощо.

2. Це явище вимагає детального соціального, андрагогічного та медичного дослідження, створення новітніх освітянських технологій, заснованих на «живому» спілкуванні.

3. «Кліпове мислення» володіє не тільки недоліками - це розвиток одних когнітивних навичок за рахунок інших, це нині ще «дитина в колисці», і що з неї виросте залежить від нас.

\section{Література}

1. Нестерова Л. Ю. Развитие клипового мышления у студентов в системе высшего образования посредством опорных граф-схем / Л. Ю. Нестерова, С. В. Напалков // Вестник Нижегородского университета им. Н. И. Лобачевского. Серия : Социальные науки. 2016. - № 4 (44). - С. 207-215.

2. Інформатизація освіти і їі наслідок - формування «кліпової» свідомості та «кліпового» мислення - крок уперед чи назад у медичній освіті? / Т. І. Ярмола, О. В. Мохначов, Л. А. Ткаченко [та ін.] // Удосконалення якості підготовки лікарів в сучасних умовах, мат. наук.-практ. конф., м. Полтава, 2016. - С. 254-256.

3. Исаева А. Н. «Клиповое мышление»: психологические дефициты и альтернативы (пространственный фокус) / А. Н. Исаева, С. А. Малахова // Мир психологии. - 2015. - № 4 (84). - С. 177-191.

4. Семеновских Т. В. Феномен «клипового мышления» в образовательной вузовской среде / Т. В. Семеновских // Интернетжурнал «Науковедение». - 2014. - Вып. 5 (24). - С. 1-10.

5. Гич Г. М. «Кліпове» мислення молоді: друг чи ворог навчання? / Г. М. Гич // Наукові праці. Педагогіка. - 2016. - Вип. 257. Т. 269. - С. 38-42.

6. Клигуненко Е. Н. Перспективы оптимизации подготовки врачей-интернов по модулю «Неотложные состояния» / Е. Н. Клигуненко, В. В. Ехалов, В. И. Слива [ неотложных состояний. - 2012. - № 5 (44). - С. 71-74.

7. Схалов В. В. Оптимізація роботи молодого викладача в процесі підготовки лікарів-інтернів за різними фахами / В. В. Схалов, Д. М. Станін, В. А. Седінкін [та ін.] // Південно-український медичний науковий журнал. - 2016. - № 13 (13). - С. 76-78. 


\section{Василий Ехалов, Владислав Сединкин, Сергей Баранник. «Клиповое мышление» и современное высшее медицинское образование.}

Проанализированы положительные $u$ отрицательные стороньы «клипового мышления» и его влияние на прочесс обучения в системе высшего медицинского образования. Рассмотрены и предложень методы минимизации негативного влияния «клипового мылиления» на процесс подготовки специилистов. Применение известных методов обучения совместно с новыми разработками, в том числе и e-learning технологиями повысит эффективность процесса обучения $u$ значительно улучшит уровень профессиональной подготовки.

Ключевые слова: «клиповое мышление», высшее медицинское образование, образовательный прочесс.

\section{Vasyl Yechalov, Vladyslav Sedinkin, Sergey Baranik. «Clip- thinking» and modern medical education.}

In article the present phenomenon «clip-thinking» is described. The positive and negative aspects of "clip-thinking» and its influence on the learning process in the system of medical education are analyzed. Methods for minimizing the negative influence of «clip-thinking» on the process of training specialists are considered and proposed. Application of known methods of training together with new development including e-learning technologies will increase efficiency of process of training and considerably will improve professional standard.

Keywords: "clip thinking», medical education, educational process.

Стаття надійшла до редакційної колегії 27.10.2017

\section{Інформація про авторів:}

Єхалов Василь Віталійович - кандидат медичних наук, доцент, Державний заклад «Дніпропетровська медична академія MO3 України».

Седінкін Владислав Анатолійович - кандидат медичних наук, доцент, Державний заклад «Дніпропетровська медична академія MO3 України».

Бараннік Сергій Іванович - доктор медичних наук, професор, Державний заклад «Дніпропетровська медична академія MO3 України». 